\title{
Character Values in the Superflex Learning Model
}

\author{
Huriah Rachmah*, Jajang H. Hendrawan \\ Social Science Education Program \\ STKIP Pasundan \\ Cimahi, Indonesia \\ *huriahrachmah@stkippasundan.ac.id
}

\author{
Rudy Gunawan \\ Social Science Education Program \\ Muhammadiyah Prof.Dr. Hamka University \\ Jakarta, Indonesia \\ rudy_gunawan@uhamka.ac.id
}

\begin{abstract}
This paper was taken from the results of research conducted by researchers in 2016 and 2017 at Cimahi inclusion school. The purpose of this study is to produce a learning model to help teachers in overcoming students who have emotional and behavioral disorders (EBD). Background teachers from general education for teachers apply the same education to EBD students in the classroom. Research is done by using research and development method. In 2016 resulted in an agreement with teachers to conduct a limited model trial. In 2017 conducted a limited trial in three Cimahi inclusion primary schools. Based on the results of the research, found the character value that can be raised after doing the superflex learning model. The values of the characters that appear are honest, curiosity, communicative, social and responsibility. This character can help EBD students to be more confident in associating with their environment.
\end{abstract}

Keywords-character; emotional and behavioral disorder; social cognition; superflex learning; value

\section{INTRODUCTION}

Character education needs to be exemplified to the child from an early age because the child is the most rapid figure absorb all the views, heard and felt. If the child is given a good example, then his behavior will be good. However, if parents give a bad example it will cause emotional and behavioral disorders in children. One of the causes of the emergence of emotional and behavioral disorders is conflict with parents and children. The results of research in one school, children from broken home family have behavioral abnormalities such as impolite to the teacher, disturbing friends, moody, quiet and lazy [1].

Another study explains, as many as 61 respondents from 315 elementary school students experience behavioral disorders (EBD) and most often experienced by girls and children aged 10 years. The behaviors shown are opposing behaviors and behavioral disorders [2]. Children who have emotional and behavioral disorders are generally difficult to adjust to the environment so that it will affect the learning outcomes [3]. Personal emerged from EBD children is lack of confidence, always suspicious of others, low self-esteem, selfisolation, excessive anxiety and frequent fights/clashes.

Overcoming EBD children can be done with social learning. Social learning teaches students into concepts of social thought and social skills [4]. The social thinker will think about whether the action will be expected or not expected [5]. The purpose of social thinking is to direct students to think deeper about the social situation at hand. The results reveal that students who are considered to have "inappropriate behavior" require direct instruction as a substitute for reprimand because social competence is not produced from a set of social skills memorized, but is the result of a process of social awareness and self-ability to adapt according to social conditions faced [6]. Studying social thinking will help students recite the power of superflex characters [4].

Learning Superflex is a learning model that teaches learners to become a social thinker [7]. The superflex learning curriculum began to be developed in the United States in 2008 featuring a superhero figure that can help a person socialize based on the principles of social cognition [8]. The superflex learning model utilizes the images included in the comic book by displaying superhero characters as the main character named Superflex.

In addition to superflex characters, also featured characters who need help to be more flexible in social thinking called Unthinkables Team and flexible characters that is Thinkables Team. Madrigal and Winner describe Unthinkables Team as an inflexible character and lack the social cognitive ability [9]. This figure consists of 14 characters that describe inflexible social skills. Another character called Thinkables Team is a character that appears after the Unthinkables Team character is omitted by Superflex. Superflex learning helps students with emotional and behavioral disorders to adapt to their environment, have self-awareness and adapt to the development of learners [10].

The purpose of the study is based on characterizations and characters raised in superflex learning. The study was conducted on the positive and negative characters featured in superflex learning. Positive characters are told, is expected to assist students in developing the character himself, especially the character associated with social. The results of the interim research on Superflex learning can identify the values of any character that emerges so as to assist the students in developing social skills and social thinking skills $[11,12]$.

\section{LITERATURE REVIEW}

\section{A. Character Values}

Value means as useful, empowered, valid and strong in behavior. Setiawan expresses the value of being abstract, ideal, requiring appreciation and attachment to one thing that has to do with human belief [13]. Values are related to a character 
(habit). Character is a strong inherent character in a person who obtained from the habit from an early age [14-16]. Lickona mentions that character is a person's natural traits in responding to situations with morally owned and manifested through concrete actions such as good behavior, honest, responsible, and other noble characters [16]. Character is a trade mark owned by humans, if not trained will be weak, but if trained it becomes a good habit [17].

Character education is the development of the ability to be self, live peacefully and make the world as a charity field that can be implemented by students to be able to behave well by making changes [17]. Environment is one of the important things in supporting a character education. Variations of character education methods by way of assignment, habituation, training, learning and modeling [18]. Proper character education method will produce moral character values so as to form components of good character that is moral knowing, moral feeling and moral action [15].

Character education areas include cognitive development, life good education, life skills education, health education, conflict resolution, ethical philosophy and social or moral learning. Thus, character education is an effort so that students can recognize, care and internalize values so that it can become a useful human [19]. Iskandarwassid and Sunendar explains that students in elementary education are expected to learn the skills that are self-help skills, social skills, school skills and playing skills [20].

The Ministry of National Education strengthens the implementation of character education in the educational unit has identified 18 values originating from religion, Pancasila, culture and National Education Objectives are: Religious, Honest, tolerance, discipline, hard work, creative, independent, democratic, curiosity, nationality, homeland love, respect for achievement, friendship/ communicative, peace loving, reading, caring environment, social care, responsibility [21].

\section{B. Superflex Learning}

Learning superflex is a learning to improve students' social thinking skills and aims to enable students to solve problems related to social skills [8]. Students learn to recognize their inner character and improve the negative character that is in themselves [12]. The Superflex ${ }^{\circledR}$ curriculum was developed based on the theory of cognitive behavioral approaches to explore social process thinking. According to Attwood the goal of cognitive behavior theory is to increase one's awareness about the impact of their behavior on others and self [22].

For the learners themselves the Superflex ${ }^{\circledR}$ curriculum can help them improve their knowledge of social expectations, raise self-awareness of their own behavior and learn how to modify negative behavior using a super-flexible strategy. The Superflex® curriculum can be used by psychologists, teachers and parents by learning the concepts of social cognition with reference to social thought books [7].

Learners who can benefit from elementary, junior and senior high school students.

Learning superflex using comics as a medium of learning. In the comic book, there are figures showing negative characters called Unthinkables Team and characters with positive characters called thinkables team [8, 9]. The figures can be seen in Table I below:

TABLE I. CHARACTER UNTHIKABLES AND THINKABLES TEAM IN SUPERFLEX LEARNING

\begin{tabular}{|c|c|c|c|}
\hline \multicolumn{2}{|c|}{ Unthinkables Team } & \multicolumn{2}{|c|}{ Thinkables Team } \\
\hline Figure & $\begin{array}{c}\text { Character } \\
\text { Make to }\end{array}$ & Figure & Character Help to \\
\hline Rockbrain & $\begin{array}{l}\text { Cannot create } \\
\text { ideas }\end{array}$ & Rex Flexiator & Creative thinking \\
\hline Space Invader & $\begin{array}{l}\text { Interfere with } \\
\text { the affairs of } \\
\text { others }\end{array}$ & $\begin{array}{l}\text { Space } \\
\text { Respecter }\end{array}$ & $\begin{array}{l}\text { Respect the } \\
\text { privacy of others }\end{array}$ \\
\hline Glassman & $\begin{array}{l}\text { Easy to get } \\
\text { angry }\end{array}$ & $\begin{array}{ll}\text { Kool } & \text { Q. } \\
\text { Cumber } & \end{array}$ & $\begin{array}{l}\text { Be calm when } \\
\text { there is a problem }\end{array}$ \\
\hline Brain Easter & $\begin{array}{l}\text { Wishly- } \\
\text { washy }\end{array}$ & Focus tron & $\begin{array}{l}\text { Focus on listening } \\
\text { to other peaple's } \\
\text { conversation }\end{array}$ \\
\hline Worry Wall & $\begin{array}{l}\text { Always } \\
\text { worried }\end{array}$ & PosiTina & Beat the worry \\
\hline WashFunnyOnce & $\begin{array}{l}\text { Joke without } \\
\text { looking at the } \\
\text { situation }\end{array}$ & HumorUs & $\begin{array}{l}\text { Knowing the time } \\
\text { and place to joke }\end{array}$ \\
\hline One-Sided Sid & $\begin{array}{l}\text { Just talking } \\
\text { about yourself }\end{array}$ & $\begin{array}{l}\text { Other Side } \\
\text { Sally }\end{array}$ & Take turns talking \\
\hline D.O.E & $\begin{array}{l}\text { Too } \\
\text { competitive }\end{array}$ & I.O.E & $\begin{array}{l}\text { Working together } \\
\text { in terms }\end{array}$ \\
\hline Body Snatcher & $\begin{array}{l}\text { Cannot } \\
\text { socialize }\end{array}$ & Stick Withem & $\begin{array}{l}\text { Be part of the } \\
\text { group }\end{array}$ \\
\hline Energy Hare-y & Too lively & $\begin{array}{l}\text { Mediation } \\
\text { Matt }\end{array}$ & $\begin{array}{l}\text { Stay calm so you } \\
\text { can make the best } \\
\text { decisions }\end{array}$ \\
\hline Un-Wonderer & $\begin{array}{l}\text { Do not like to } \\
\text { socialize }\end{array}$ & $\begin{array}{l}\text { SociaLee } \\
\text { Wonderer }\end{array}$ & $\begin{array}{l}\text { Interesting and } \\
\text { not boring in the } \\
\text { conversation }\end{array}$ \\
\hline Mean Jean/Gean & $\begin{array}{lll}\text { Act like a } & \text { liss } \\
\text { boss } & & \end{array}$ & $\begin{array}{l}\text { Nice } \\
\text { Bryce/Brice }\end{array}$ & $\begin{array}{l}\text { Staying friends } \\
\text { with people you } \\
\text { do not like }\end{array}$ \\
\hline
\end{tabular}

a. Source: $[8,9]$

\section{METHOD}

This research is part of research conducted from 2016 to 2017 using descriptive qualitative methods. The informants in this study were three students who had problems with behavior. The process of data collection is done by interviewing and observing after students get superflex learning. The questions in the interviews were only taken in the relevant part of this research, namely about the superhero characters who were liked, the students' behavior during the class, what was most liked and disliked during school and the behavior changes felt by students after getting an overview of superflex, unthinkables team and thinkables team. Data analysis is done by data reduction, data presentation and conclusion (verification) on the results of interviews and observations

\section{RESULTS AND DISCUSSION}

Interviews were conducted to each student before and after the action. The action is to introduce to superflex characters through the use of media cards and images. Before entering the superflex, students are introduced to the concept of social cognition. When asked about superhero characters, one person answered not knowing because they never watched television while the other two students responded to transformers and 
power ranger. The question of what is done in the everyday class shows that the first student expresses his dislike to some friends by disturbing the student, the second student reveals that he likes to joke during the learning process. The third student tends to be quiet and often daydreaming so that lack of focus every answering the questions posed.

Questions about what students love most are answered by student A by drawing, student's favorite B is to move around seating, student $\mathrm{C}$ answer does not know. Student $\mathrm{A}$ and student $\mathrm{C}$ reply that they do not like to be asked too much by the teacher, while student B does not like if always reprimanded by the teacher. When finished doing the observation activities, each student was asked questions about the perceived change after knowing about the superflex and the characters inside, the three students answered they were happy to change even though the old trait still exists. Students agree that they are able to identify the social traits within them.

The results of the observations showed students are enthusiastic in studying superflex characters. Although initially difficulty determining the character of unthikables in him, but with the guidance of the teacher, finally students are able to identify the negative character in him. In the last few meetings, students are faced with a problem that is usually not able to overcome, but slowly managed to overcome by them and bring the character of thinkables in him. Students feel happy because they are able to make changes. Student A reduces interference to his friends, student B though still joking, but has been able to refrain from joking in times of serious and $\mathrm{C}$ students become more open to the environment.

The results showed that teachers have explained the concept of social observation before introducing the superflex. The basic concept of social thinking (social cognition) is given by the teacher to the students by engaging the students in social observations in the classroom. Social cognition theory sees one's reaction from the interaction with others through the process of habituation, imitation and characterization [23]. The difficulty that teachers face is the process of recognition that requires patience, because this concept can not be taught in a hurry.

After students understand the concept of social cognition, students are introduced to Superflex. Previously, the students were asked to mention the superhero character that is often watched, after which the teacher explained that what the students watch is a fictional character. It is important to emphasize students because Superflex is not in others, but Superflex has students themselves [24]. At this stage, students are asked to describe themselves starting from the physical characteristics of each. Superflex can not be used on students who are unable to distinguish between imagination and reality.

The characters of each student appear as they explore the character of the unthikables team. At first, the students felt that all the characters of unthikables were on him. However, after being given an understanding at the next meeting, then the students are able to see each other's tendencies. Student A often annoys her friend and realizes in her there is an invader space. Student B realizes she often jokes out of place, even when the teacher is explaining in front of the class. Student B realizes that within her is the character of WasFunnyOnce. Student C feels shy to socialize and chooses to be quiet, initially student $\mathrm{C}$ is unable to identify the character that is in him, and does not want to express it until assisted by the teacher, so that student $\mathrm{C}$ realizes that in him there is Un-Wonderer character.

Student's discovery of her own character helps teachers to apply strategies in applying social thinking. The social detective concept introduces social learning combined with the concept of social thinking so that each student will experience different experiences while in his environment. Emotional social learning can assist students in encouraging positive academic performance of social behavior as well as dealing with emotional stress [25]. Creativity of teachers in developing social cognition of learners, will help students to develop social character.

At the end of the observation, students can find ways to overcome their shortcomings. People in the thinkables team are selected by the students, then the students are told how to overcome the unthinkables team. Students are asked to continue to practice social thinking because it will assist learners in identifying social problems, accustomed to doing things so that students can finally realize the social character in themselves [26].

Character values in superflex learning that can be used as patterns of behavior that is formed from the habits of each individual is honest, curiosity, friendship, social care and responsibility. As expressed by Hasan, this is in line with the character values identified from the sources of character education, namely [20]:

- Honest is the behavior that is based on the effort to make yourself into a person who can be trusted.

- Curiosity is an act and an attitude to know more about everything that is learned, seen and heard.

- Friendly / communicative is an act that shows the pleasure of talking, getting along, and working with others

- Social care is an act shown by giving help to others

- Responsibility is the attitude and action to execute its duties and obligations in society.

In superflex learning, honesty is demonstrated by the belief that students can transform themselves, thus earning the trust of others that students can be better than ever. When students make changes in themselves then the students must find out the characters that must be changed so that it can become a better social creature. This impacts on the better communication skills of students and more concerned about friends and environment. In the end students are able to take responsibility for what is done and be able to realize mistakes and want to correct the mistake.

\section{CONCLUSION}

Learning superflex is a learning process that teaches students to be flexible in interacting at home, school and community environment. There are character values that can be trained and familiarized to students so that students have good 
social cognition. Social cognition requires students to always think of every action, deed and word at the time of social interaction. The results of the study show that the students change from the quiet to be brave to speak, likes to interfere with being more patient and caring, from the jokes to be more calm and able to place themselves and the situation. Through superflex learning, students learn to be honest, have curiosity, communicative, social care and responsibility

\section{ACKNOWLEDGEMENTS}

Acknowledgment of the researcher to the Ministry of Research and Technology Higher Education through the Director General of Research and Community Service that has provided research, Head of STKIP Pasundan and its representatives, Head of Research and Community Service Institute STKIP Pasundan, Rector of Muhammadiyah University Prof. Dr. Hamka Jakarta which has allowed its best lecturer to take part in this research, Cimahi City Government through the National Unity and Political Entity which has given permission to research, Principals in 17 (seventeen) Inclusive Elementary School in Cimahi, Teachers who have been the research respondents, Head of Magister Program Social Science Education STKIP Pasundan, and all parties who help directly or indirectly so that this research can be completed. Hopefully all good deeds get a reply from Allah SWT.

\section{REFERENCES}

[1] M. Aziz, "Perilaku Sosial Anak Remaja Korban Broken Home dalam Berbagai Perspektif (Suatu Penelitian di SMPN 18 Kota Banda Aceh). Social Behavior of Youth Children of Broken Home Victims in Various Perspectives (A Study at Junior High School 18 Banda Aceh)," Jurnal Al-Ijtimaiyyah, vol. 1, no. 1, pp. 30-50, Januari-Juni 2015.

[2] I. H. Christie, T. M. Kaunang, and H. Munayang, "Gambaran Gangguan Perilaku pada Anak yang Mengalami Kekerasan di Enam Sekolah Dasar Kecamatan Malalayang Kota Manado (Picture of Behavioral Behavior in Violent Children in Six Elementary Schools of Malalayang Subdistrict, Manado City)," Jurnal Kedokteran Klinik, vol. 1, no. 3, pp. 4755, April 2017.

[3] A.A. Anggaswari and I. W. Budisetyani, "Gambaran Kebutuhan Psikologis pada Anak dengan Gangguan Emosi dan Perilaku (Tinjauan Kualitatif dengan Art Therapy sebagai Metode Penggalian Data)(Description of Psychological Needs in Children with Emotional Disorders and Behavior)," Jurnal Psikologi Udayana, vol. 3, no. 1, pp. 86-94, 2016

[4] M.G. Winner and P. Crooke, "9 Strategies to Encourage Generalization of Social Thinking® Concepts and Related Social Skills" Retrieved from Social Thinking Website: https://www.socialthinking.com/Articles?name $=9 \% 20$ Strategies $\% 20$ to $\%$ 20Encourage $\% 20$ Generalization $\% 20$ of $\% 20$ Social $\% 20$ Thinking $\% 20$ Con cepts $\% 20$ and $\% 20$ Related $\% 20$ Social $\% 20$ Skills, Accesed January 22, 2018.

[5] M. G. Winner, "How is Teaching Hidden Rules Different From Teaching About Expected/Unexpected Behavior?" Retrieved from: https://www.socialthinking.com/Articles?name=Hidden-Rules-ifferentfrom-Expected-Unexpected, Accesed February 14, 2017.

[6] K.Z. Palmer, "Are You Teaching Deeply, or Redirecting Behavior? Using the Social Thinking Vocabulary Terms Expected and Unexpected" Retrieved, from Social Thinking Website: https://www.socialthinking.com/Articles?name=UsingtheTermsExpecte dUnexpected, Accesed January 24, 2018.
[7] M.G. Winner, "Superflex, the Team of Unthinkables and the Five-Step Power Plan" Retrieved, from social thinking website: http://www.socialthinking.com/what-is-social-thinking/superflex-theunthinkables-and-the-five-step-power-plan, Accesed Maret 28, 2015

[8] S. Madrigal and M.G. Winner. Superflex: A Superhero Social Thinking Curriculum, 2008

[9] K.E. Baker, Detectives and Superheroes: A Pilot Study Teaching Flexible Thinking in Social Situations to a Child with High Functioning Autism. (Thesis. St. Catharines, Ontario: Faculty of Social Sciences, Brock University), 2011

[10] B. Linton, "Social Thinking Across the Home and School Da: The I LAUGH Model of Social Thinking" Retrieved from Social Thinking Publishing: http://www.osspeac.org/wp-content/uploads/2015/08/DayA-and-M-ppt-handouts.pptx.pdf, 2015

[11] H. Rachmah, R. Gunawan, and M. Mulyani, "Model Pembelajaran Pembelajaran Superflex untuk Mengeksplorasi Kemampuan Kognisi Sosial (Laporan Penelitian Tahun Pertama)-(Learning Model of Superflex Learning to Explore Social Cognition Ability (First Year Research Report))," Cimahi: STKIP Pasundan, 2016

[12] H. Rachmah, R. Gunawan and J.H. Hendrawan, Model Pembelajaran Superflex untuk Mengeksplorasi Kemampuan Kognisi Sosial (Studi pada Siswa di Sekolah Dasar Inklusi Kota Cimahi Jawa Barat)(Superflex Learning Model for Exploring Social Cognitive Ability). STKIP Pasundan. Cimahi: DRPM Kemristekdikti dan STKIP Pasundan, 2017.

[13] M. Arfin, Implementasi Nilai-nilai Pendidikan Karakter pada Sekolah Dasar Negeri Mannuruki Makassar. Translate: Implementation of Character Education Values at Mannuruki Elementary School of Makassar. U(niversitas Islam Negeri Alauddin Makassar, Program Pascasarjana. Makassar: Program Pascasarjana UIN Alauddin Makassar), 2017.

[14] F. Hidayatullah, Pendidikan Karakter Membangun Peradaban Bangsa (Character Education Building Nation Civilization). Surakarta: Yuma Pustaka, 2010.

[15] D. Suhardi, "Peran SMP Berbasis Pesantren sebagai Upaya Penanaman Pendidikan Karakter Kepada Generasi Bangsa (The role of the First Secondary School Based Pesantren as an Effort to Cultivate Character Education to the Nation Generation)," Jurnal Pendidikan Karakter, vol. II, no. 3, pp. 316-328, 2012.

[16] N. Nuraida, "Pengembangan Nilai-Nilai Karakter melalui Pendidikan Pencak Silat untuk Anak Usia Dini (Studi Kasus di Paguron Pencak Silat Galura Panglipur Bandung)-(Development of Character Values through Pencak Silat Education for Early Childhood)," Tunas Siliwangi, vol. 2, no. 1, pp. 59-77, April 2016,

[17] M.A. Ramdhani, "Lingkungan Pendidikan dalam Implementas Pendidikan Karakter (Educational Environment in Character Education Implementation)," Jurnal Pendidikan Universitas Garut (Journal of Education Garut University), vol. 8, no. 01, pp. 28-37, 2014.

[18] Mulyasa, Manajemen Pendidikan Karakter (Character Education Management). Bandung: Bumi Aksara, 2013.

[19] Syafaruddin, Pendidikan dan Pemberdayaan Masyarakat (Education and Community Empowerment). Medan: Perdana Publishing, 2012.

[20] N. Hidayah, "Penanaman Nilai-Nilai Karakter dalam Pembelajaran Bahasa Indonesia di Sekolah Dasar (The Cultivation of Character Values in Indonesian Language Learning in Elementary School)," Jurnal Pendidikan dan Pembelajaran Dasar "Terampil", vol. 2, no. 2, pp. 190204, December 2015.

[21] H. Rachmah, "Nilai-Nilai dalam Pendidikan Karakter Bangsa (Values in Nation Character Education)," E-Journal WIDYA Non-Eksakta, vol. 1, no. 1, pp. 7-14, Juli-Desember 2013.

[22] M.G. Winner, "Introduction to Social Thinking" Retrieved from social thinking website: http://www.socialthinking.com/what-is-socialthinking/introduction, 2011, September 28

[23] T. Sudjanika, "Tinjauan Kognisi Sosial terhadap Sosial Budaya (Social Cognition Overview of Socio-Culture)" Jurnal al-Tsaqafa, vol. 13, no. 1, pp. 159-176, 2016.

[24] P. Crooke and M.G. Winner, "10 DOs and DON'T for Teaching Superflex,” Think Social Publishing, inc., Maret 2015. 
[25] L. Dusenbury and R.P. Weissberg, "Social Emotional Learning in Elementary School: Preparation for Success," Pennsylvania State University: Edna Bennett Pierce Prevention Research Center, 2017.
[26] C. Jones, "Networked Learning - a social practice perspective," The 6th International Conference on Networked Learning pp. 616-623, University of Lancaster, 2008. 